\title{
Natural History and Ecology of the Critically Endangered Puerto Rican Plains Coquí, Eleutherodactylus juanariveroi Ríos-López and Thomas, 2007 (Amphibia: Anura: Eleutherodactylidae) ${ }^{1}$
}

\author{
Neftalí Ríos-López ${ }^{2}$, Marissa Reyes-Díaz ${ }^{2}$, Lelanee Ortíz-Rivas ${ }^{2}$, \\ Josué E. Negrón-Del Valle ${ }^{2}$, and Christina N. de Jesús-Villanueva ${ }^{3}$
}

\begin{abstract}
We documented the population dynamics and reproductive biology of Eleutherodactylus juanariveroi from a fresh water herbaceous wetland. The species' population density increased only during the rainy months (May to November) and decreased during the dryer months (January to April). The species showed microhabitat selection for perching/calling, and for egg clutch deposition. Egg clutches were exclusively found on leaf axils of large individuals of Sagittaria lancifolia (bulltongue arrowhead). Eleutherodactylus juanariveroi has the second highest proportion of multiple clutches produced among Puerto Rican Eleutherodactylus. The species displays no parental care, making it the third species in the genus with no parental care. Egg masses in clutches are enclosed in a thick jelly layer, which is unique among Puerto Rican Eleutherodactylus. The species' population dynamics is influenced by a synergism between availability of suitable sites for reproduction, rainfall seasonality, and a presumable important contribution from the species' egg morphology as a reproductive strategy leading to high hatching success without parental care.
\end{abstract}

Key Words: Bulltongue Arrowhead, Sagittaria lancifolia, Coquí Llanero, Critically endangered species, Eleutherodactylus juanariveroi, Eleutherodactylus, Habitat selection, Parental care.

Wetlands are among the most threatened ecosystems worldwide, mainly as a result of human disturbances like drainage and landfill for urban and industrial development (Mitsch and Gosselink, 2007). Consequently, many species of amphibians and reptiles are threatened as wetlands represent an important ecological connection between terrestrial and aquatic environments essential for their survival and reproduction (e.g. Semlitsch and Bodie, 1998; Brodman et al., 2006). Therefore, as we face worldwide declines in amphibian and reptile populations (Gibbons et al., 2000; Young et al., 2001; Blaustein et al., 2011), documenting the myriad ecological requirements of wetland herpetofaunal components is of prime importance for the development of effective species conservation and ecosystem management plans.

The genus Eleutherodactylus (Anura: Eleutherodactylidae) comprises 185 species distributed throughout the West Indies, southern USA (Florida, Texas), Mexico, Guatemala, and Belize (Hedges et al., 2008). Previous studies on species of Eleutherodactylus, however, have generally dealt with species

\footnotetext{
${ }^{1}$ Submitted on May 5, 2014. Accepted on May 21, 2014, Last revisions received on May 27, 2014.

2 Department of Biology, University of Puerto Rico-Humacao, Call Box 860, Humacao, Puerto Rico, 00792. E-mail: neftali.rios@upr.edu, neftalirios@yahoo.edu

${ }^{3}$ Department of Biology, University of Puerto Rico-Río Piedras, P. O. Box 23360, San Juan, Puerto Rico, 00931. E-mail: $\underline{\text { chri360@ gmail.com }}$
} 
descriptions and evolutionary relationships, while only a few studies exist on the population ecology and reproductive biology of the vast majority of the species (Townsend, 1996; Henderson and Powell, 2009; but see Burrowes, 2000 and Fong et al., 2010). For example, only 37 of 161 (23\%) species of Eleutherodactylus in the West Indies have received some non-taxonomic attention, but only in relation to their natural history, while three of the four most studied species belong to the biogeographic region of Puerto Rico in the Caribbean (i.e. the Common Coquí, E. coqui Thomas, 1966; the Cave-Dwelling Coquí, E. cooki Grant, 1932; and the Red-eyed Coquí, E. antillensis Reinhardt and Lutken, 1863; Henderson and Powell, 2009). In addition, the vast majority of ecological studies of Eleutherodactylus were concerned primarily forested nonflooded habitats, with similar studies from herbaceous habitats and semiaquatic situations virtually absent in the Eleutherodactylus literature. Few known species of Eleutherodactylus, however, are found in riverine and semiaquatic situations. Riverine Eleutherodactylus are usually found along riverbanks and small upland streams (reviewed in Joglar, 1998; Hedges et al., 2008; Fong et al., 2010), while one species, the Haitian Marsh Frog, E. caribe Hedges and Thomas, 1992, inhabits Red Mangrove, Rhizophora mangle L. (Rhizophoraceae), forests, , and one species, E. juanariveroi Ríos-López and Thomas, 2007, is known only from a palustrine (fresh water) wetland in Toa Baja, northern Puerto Rico.

Eleutherodactylus juanariveroi, also known as the Coquí Llanero, is part of a small radiation of three Puerto Rican species, which also includes the highland E. gryllus Schmidt, 1920 (Cricket Coquí) and the ovoviviparous E. jasperi Drewry and Jones, 1976 (Golden Coquí) (Hedges et al., 2008). Internal fertilization is presumed for these species (as it is for Eleutherodactylus in general; Townsend, 1996). In addition, one of these three species have experienced a rapid population decline (E. gryllus; Burrowes et al., 2004). One species, E. jasperi, is presumably extinct (IUCN 2012), and for E. juanariveroi, most of its natural history and ecological requirements are largely unknown. Eleutherodactylus juanariveroi, however, has the smallest geographic distribution (ca. 260 ha palustrine herbaceous wetland; USFWS, 2012) and smallest body size among Puerto Rican Eleutherodactylus (mean SVL: $14.7 \mathrm{~mm}$ in males; $15.8 \mathrm{~mm}$ in females; Ríos-López and Thomas, 2007). In October 2012, E. juanariveroi was designated endangered because of major threats to its wetland (USFWS, 2012). Threats include, but are not limited to, urban development, unregulated recreation activities, leachate from a municipal landfill, removal of vegetation for flood control, and invasive plant species among other threats.

The main objectives of our study were to document the natural history of $E$. juanariveroi, and to determine the abiotic and biotic factors in E. juanariveroi's wetland habitat that influence the species' population ecology and reproductive biology. 


\section{Methods}

Study Site and Vegetation Sampling. Eleutherodactylus juanariveroi is found in a small palustrine herbaceous wetland (ca. 260 ha [USFWS, 2012]; $18^{\circ} 26.127^{\prime} \mathrm{N}, 66^{\circ} 12.092^{\prime} \mathrm{W}$ ) at $1-6 \mathrm{~m}$ above sea level (asl) located at the northernmost limestone belt in the Toa Baja municipality, northern Puerto Rico (Figure 1).

The study area is classified as Subtropical Moist Forest Life Zone (Ewel and Whitmore, 1973). Average annual ambient temperature is mildly seasonal (mean $\pm 1 \mathrm{SD}=25.2 \pm 1.3{ }^{\circ} \mathrm{C}$; all means are reported $\pm 1 \mathrm{SD}$ throughout the manuscript) with months between May and November being the warmest (Figure 2A). Nocturnal and diurnal relative humidity varies little, reaching 100\% and $60 \%$, respectively, and do not show seasonality (Figure 2B). The area has a mildly seasonal average annual rainfall of $1,700 \mathrm{~mm}$ with most of the rain occurring from May to November (Eusse and Aide, 1999; Figure 2C). The wetland is seasonally flooded between May and January and reaches the lowest water table from late February to early April (NRL, pers. obs.): during 2005, the average annual standing water depth was $0.3 \pm 0.2 \mathrm{~m}$ (max. $0.7 \mathrm{~m}$ in late July 2005; minimum water level reached $0.2 \mathrm{~m}$ during most of the year).

We established five $3 \times 30 \mathrm{~m}$ vegetation transects, which were separated by $10 \mathrm{~m}$ from each other, in each of two sites (Site 1 and Site 2; Figure 1). These sites were approximately $400 \mathrm{~m}$ apart (Site 1, ca. $300 \mathrm{~m}$ away from the near paved road [Red Man Road] and Site 2, between 15 and $80 \mathrm{~m}$ away from this road) (Figure 1). These vegetation transects were sampled to describe and quantify the dominant microhabitat substrate types (conspicuous vegetation and miscelaneous substrate types) available to frogs. Vegetation sampling occurred once in each site on each of four occasions in 2005: 19 July, 22 August, 22 September, and 30 November in Site 1; 18 July, 19 August, 23 September, and 19 November in Site 2. On each visit, we estimated vegetation cover in $151 \times 1$ $\mathrm{m}$ plots, randomly placed along each transect, but with a minimum distance of 1 $\mathrm{m}$ between plots ( $n=150$ vegetation plots). In each plot, we estimated the percent cover of microhabitat types, and measured vegetation height and water depth in the middle of each plot.

Population sampling and ecology of egg deposition. We sampled the density of E. juanariveroi monthly between July, 2005 and July, 2006 along the five vegetation transects located at Site 1, and during July-October, 2005 and in February, 2006 along the five vegetation transects located at Site 2 (Figure 1). We used the Visual Encounter Survey and Audio Strip Transect techniques (Zimmerman, 1994; Crump and Scott, 1994) for population samplings, which were conducted between $1830 \mathrm{~h}$ and $2330 \mathrm{~h}$ at Sites 1 and 2 . We alternated the order of visits to each transect between sites on a monthly basis to minimize 

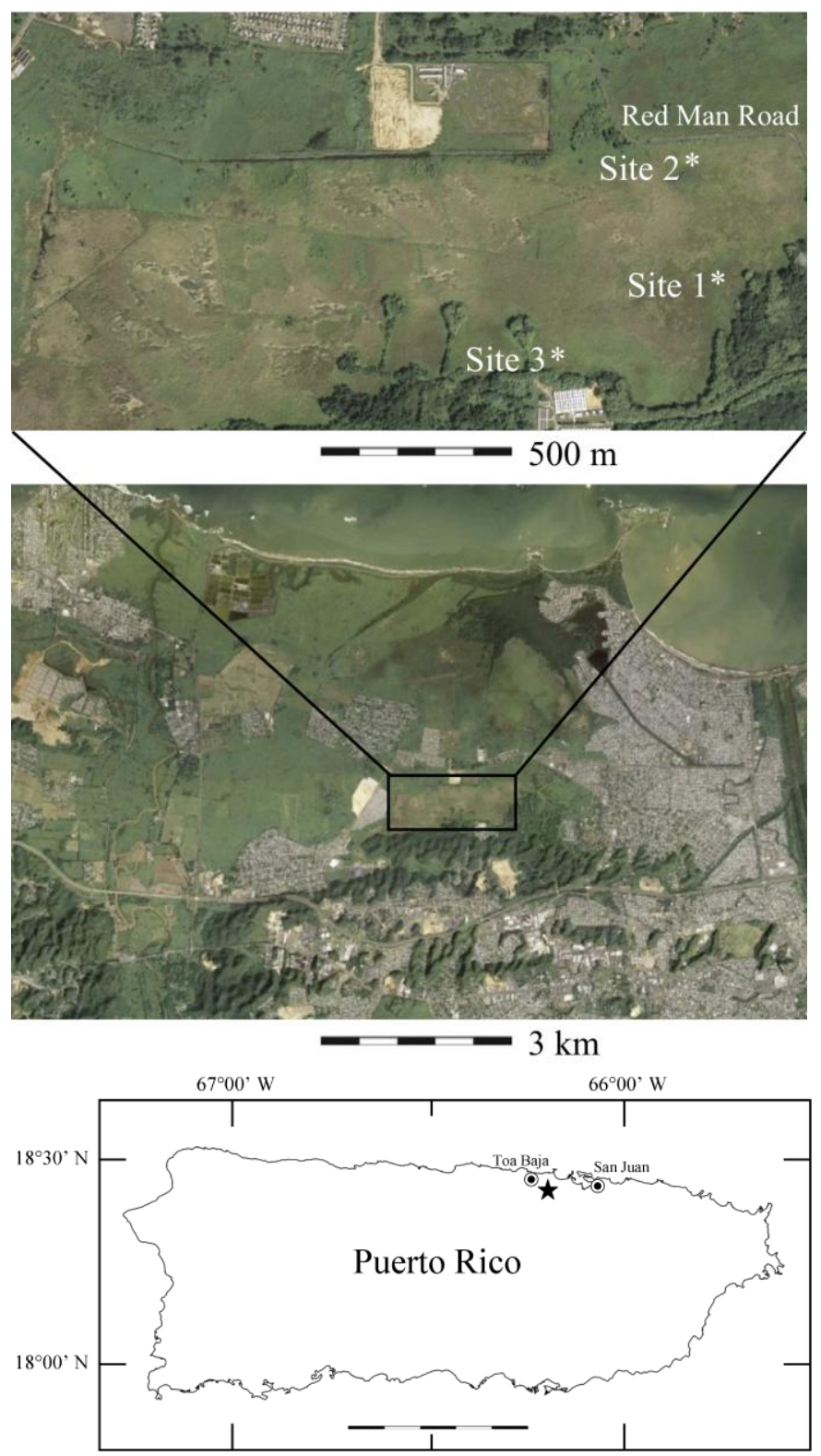

Figure 1. Aerial photographs of the study sites in the wetland (top panel), a regional detail of the wetland study site (middle panel), and map of Puerto Rico showing location of the wetland (star). Also shown are the municipality of Toa Baja and San Juan, the capital of Puerto Rico (scale bar in map $=50 \mathrm{~km}$ ). 

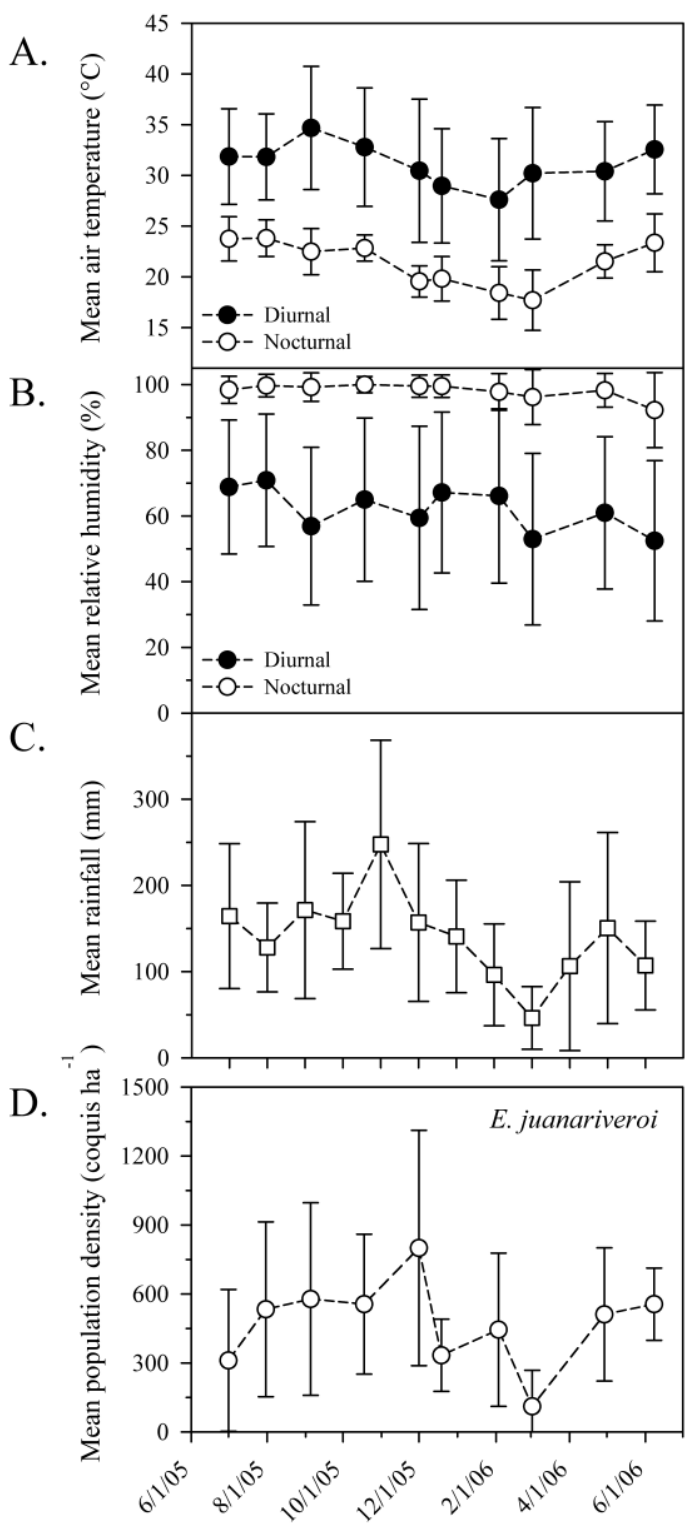

Month/Day/Year

Figure 2. Microclimate variables. A. Diurnal and noctural monthly mean air temperature during the study period. B. Monthly mean relative humidity during the study period. C. Monthly mean rainfall between 1999 and 2009. D. Monthly mean population density of E. juanariveroi $($ mean $\pm \mathrm{SD})$. 
differences in abundance data among transects because of time of the census. Population sampling at Site 2 was truncated because a helicopter that hovered close to the ground flattened all vegetation along one transect prior to the late November census. The vegetation recovered slowly (after approximately four months), and we resumed the population census in February, 2006 (fifth census). A second helicopter incident prior to the March census at Site 2, however, led us to abandon this site definitively. Consequently, we used data from Site 1 only for analyses on the variation in population density, but used all data from all sites to document aspects of the species' natural history and reproductive biology.

We monitored egg clutch production along all transects in Sites 1 and 2 between 2005 and 2006, again in Site 2 between 2009-2010, and in Site 3 between 2012-2013 (a site approximately $40 \mathrm{~m}$ from a private dirt road; Figure 1) to document aspects of E. juanariveroi's egg deposition ecology. Aspects included: single and multiple clutches percentages; clutch size; plants used for egg deposition; evidence for egg brooding (or other parental care-related behaviors); and egg predation. We assumed egg predation if the gelatinous egg mass was completely absent from a previously marked nest site since the mass frequently remains visible for several days after hatching (NRL, pers. obs.). In addition, we conducted field enclosure experiments between 2008-2009 in Site 2 and in 2012 in Site 3 to examine hatching success in the absence of adults compared to egg clutches under natural conditions (i.e. not enclosed). Experimental egg clutches were enclosed in a tube covered with a screen mesh and attached to a leaf axil, or a leaf axil with an egg clutch was wrapped with a screen mesh as a way to preclude contact with potentially guarding adults (adultexclusion trials). Enclosed egg clutches were checked weekly to document hatching success compared to hatching success of egg clutches not enclosed (natural setting).

In January 2009, we measured the height of the middle leaf blade of Sagittaria lancifolia from the water level of a subsample of 33 plants in the wetland to generate plant size bin classes and assess if egg deposition differed among plant size (i.e. plant selection for egg deposition). In this subsample, the shortest plant measured $55.5 \mathrm{~cm}$ and the tallest plant measured $206.2 \mathrm{~cm}$. We decided to use a $50-\mathrm{cm}$ bin size between the shortest and tallest plant measured to generate three plant height size classes. Plant were then readly measured along one $3 \times 70-\mathrm{m}$ census transect in Site 2 using a $2-\mathrm{m}$ aluminum pole calibrated with 10-cm reference marks, and each plant was categorized based on its size : small (between 0.5 and $1.0 \mathrm{~m}$ above water level; ), medium (>1.0 m and $1.5 \mathrm{~m}$ above water level), and large (> $1.5 \mathrm{~m}$ height above water level). After categorizing the plant, its leaf axils were checked for egg clutches of $E$. juanariveroi.

Between February and April 2009, we also measured the inner width of a leaf axil of 74 individuals of Sagittaria lancifolia found along the $3 \times 70-\mathrm{m}$ 
census transect in Site 2 and along the margin of the adjacent Annona glabra (Soursop Tree) forest stand to determine if differences in the proportion of egg clutches deposited in a given size of leaf axil could be attributed to microhabitat selection for oviposition. Each leaf axil was categorized in one of six 3-mm width classes in the 3-21 mm range of inner width, which was measured at the approximate location of egg clutches frequently found among plants. We chose half the average of the head width of adult frogs of $E$. juanariveroi $(5.8 \pm 0.4$ $\mathrm{mm}$; Ríos-López and Thomas, 2007) as a separator criteria for our size bins as it included the narrowest axils that can provide the tightest fit of an adult $E$. juanariveroi $(6 \mathrm{~mm})$ to the widest axils that provided the largest suitable breeding site in the wetland $(21 \mathrm{~mm})$. The size bin increments also enhanced visual clarity for detecting microhabitat selection for egg deposition.

Data Analyses. Because our data did not meet the assumption of linearity required by parametric correlation analyses, but met the assumption of a monotonic relationship required by non-parametric correlation analyses (Sokal and Rohlf, 1995), we used Spearman rank correlations to examine the relationship between annual pattern of monthly mean abundance of $E$. juanariveroi (population phenology) and abiotic factors (i.e. rainfall, diurnal and nocturnal relative humidity, and ambient air temperature). We used $G_{\text {adj }}$-test of independence with William's correction for small sample sizes (Sokal and Rohlf, 1995) to determine whether the proportions of frogs found on various microhabitat types could be attributed to microhabitat preference. For this test, we used the percent mean abundance of individuals found on each plant-form category and the percent plant form cover estimated for each category from the field. We used Fisher's exact test to compare hatching success between enclosure and natural settings in adult-exclusion trials. At a large spatial scale (plant scale), we use $G_{\text {adj }}$-test of independence to determine wheter the frequency of egg deposited in each plant height size class could be attributed to plant selection for egg deposition. At a smaller spatial scale (width of leaf axil within a plant), we also used $G_{\text {adj }}$ test of independence to determine whether the proportion of egg clutches found among leaf axils of different width sizes could be attributed to microhabitat selection for egg deposition. We adopted a probability $\alpha \leq 0.05$ for all statistical significance.

\section{Results}

Variation in population density of E. juanariveroi. The estimated mean annual population density of E. juanariveroi (pooled for sites 1 and 2) was 473.3 \pm 186.8 individuals $\mathrm{ha}^{-1}$. Annual pattern in monthly mean density of $E$. juanariveroi (Site 1 only) was related to changes in climate factors, in which density increased during warmer and rainy months and decreased during months with lower temperature and rainfall (between January and April) (Figure 2D). Changes in monthly mean density of $E$. juanariveroi was significantly related 
with rainfall $\left(r_{s}=0.8085, P<0.005, n=10\right)$ with little contribution from ambient temperature and relative humidity (Figure 2D).

Microhabitat use by Eleutherodactylus juanariveroi. Vegetation surveys have identified at least 31 species of vascular plants in the herbaceous dominated assemblage (Appendix 1). This plant community is characterized by a large coverage of flatsedges, Cyperus sp.; beaksedges, Rhynchospora sp.; spikerushes, Eleocharis sp., the former three, all Cyperaceae; ferns, such as Blechnum serrulatum Rich. (Blechnaceae) and the Willdenow's maiden fern, Thelypteris interrupta (Willd.) K. Iwats., (Thelypteridaceae), bulltongue arrowheads, Sagittaria lancifolia L. (Alismataceae), Southern cattail, Typha domingensis Pers. (Typhaceae), and a small forest stand of Soursop Tree, Annona glabra L. (Annonaceae). The average vegetation height and water depth (sites 1 and 2 combined) were $1.7 \pm 0.4 \mathrm{~m}$ and $0.28 \pm 0.22 \mathrm{~m}$, respectively ( $n=$ 150 plots). The mean vegetation cover of the most abundant plant substrate type in the wetland was (in decreasing order of cover): $25.2 \pm 20.7 \%$ (ferns), $17.3 \pm$ $18.4 \%$ (flatsedges), $12.7 \pm 11.9 \%$ (spikerushes), $7.4 \pm 8.9 \%$ (bulltongue arrowheads), and $0.7 \pm 2.5 \%$ (Southern cattail) (Figure 3A). The mean percent cover of standing water and of other substrates was $17.9 \pm 13.5 \%$ and $18.7 \%$ (pooled over all surfaces) (Figure 3A). The percent relative abundance of $E$. juanariveroi (pooled from sites 1 and 2) varied among plant forms: we found more individuals $(45.8 \%)$ perching and calling on ferns compared with the percent cover of ferns $(25.2 \%)\left(G_{a d j, 6}=36.68, P<0.0001\right.$; Figure 3B).

Microhabitat use for egg deposition by Eleutherodactylus juanariveroi in relation to physical attributes of the plant Sagittaria lancifolia. We found egg masses of one to five eggs (mean $=3.3 \pm 0.9$ eggs/clutch, $n=131$; egg diameter approximately $5 \mathrm{~mm}$ ) of $E$. juanariveroi only on $S$. lancifolia. Egg masses were deposited either in leaf axils (128/131 egg masses or $97.7 \%)$ or on the surface of leafs (3/131 egg masses or 2.3\%). We found a significant difference in the number of egg deposited in each plant height size class in 2009, with more eggs being deposited in larger plants: 15 eggs were found among 22 plants in the small size class; 6 eggs were found among 6 plants in the medium size class; 44 eggs were found among 21 plants in the large size class $\left(G_{a d j, 2}=7.4, P=0.025\right.$, $n=49$ ). In July-November 2005, water depth in the interior flooded portion of transects was $0.28 \pm 0.21 \mathrm{~m}$ and water depth in the margin portion of transects was $0.23 \pm 0.14 \mathrm{~m}$, but there was no statistical difference between portions $(t=$ $1.44, P=0.1489, n=92$ ). However, larger plants are frequently found towards the interior portion of the $3 \times 70-\mathrm{m}$ census transect at Site 2 (away from the wetland margin) while smaller plants are frequently found towards the beginning of the transect (towards the margin of the wetland) (Figure 4). 


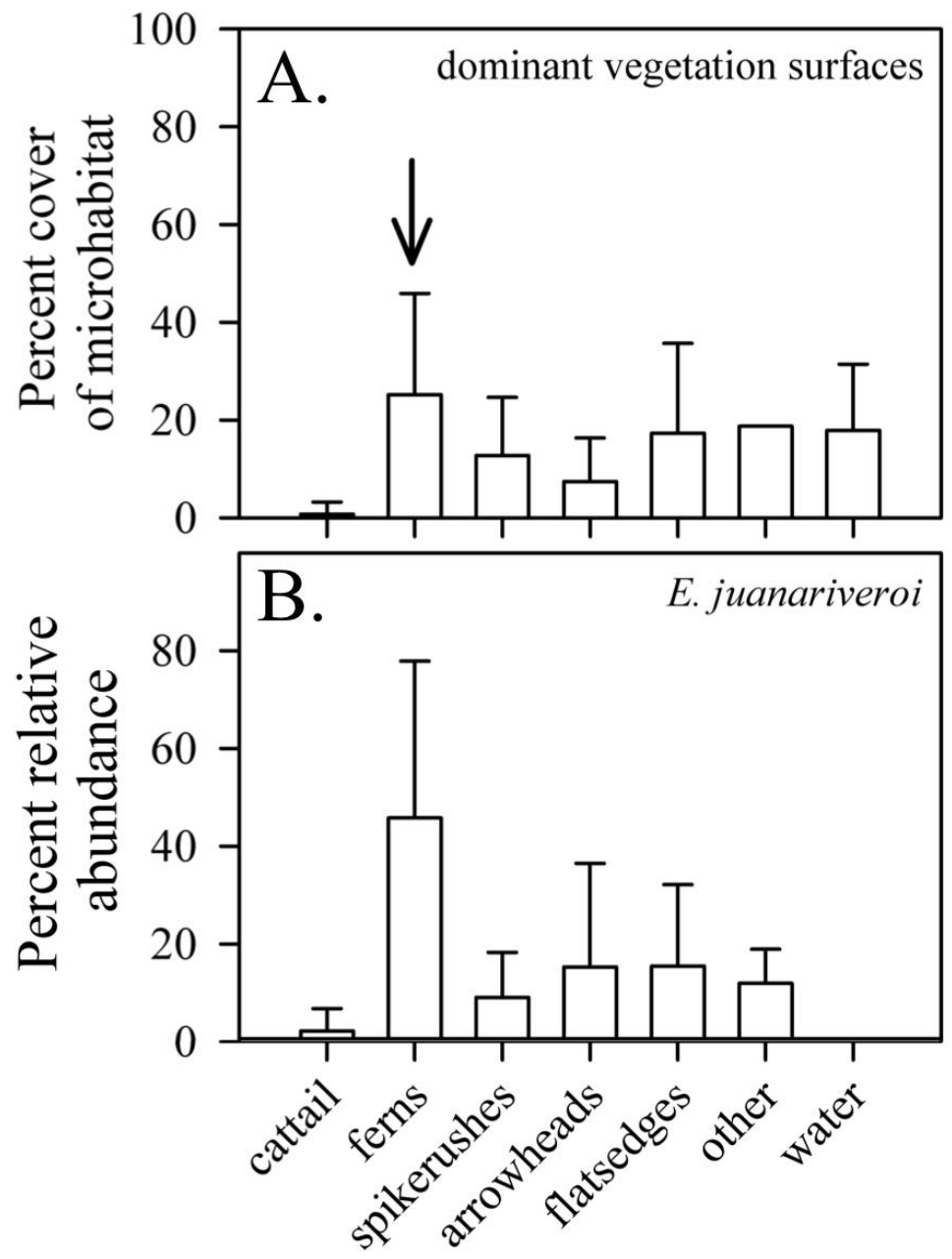

Microhabitat category

Figure 3. A. Percent cover of major substrate types that includes dominant vegetation substrates, other subtrates (a pooled combination of surfaces with lesser percent cover like small shrubs [Brassicaceae, also known as Cruciferae], grass blades [Poaceae, also known as Gramineae], marking string along each transects, narrow stems of small vines [Convolvulaceae and Fabaceae, also known as Leguminosae, Papilionoideae], and PVC (polyvinyl chloride) pipes used for transect marking), and standing water in the wetland. $\mathrm{B}$, percent relative abundance of individuals of E. juanariveroi found on each subtrate type. The arrow highlights significant differences between the proportion of calling males detected in the fern substrate compared with the percent cover of ferns. 


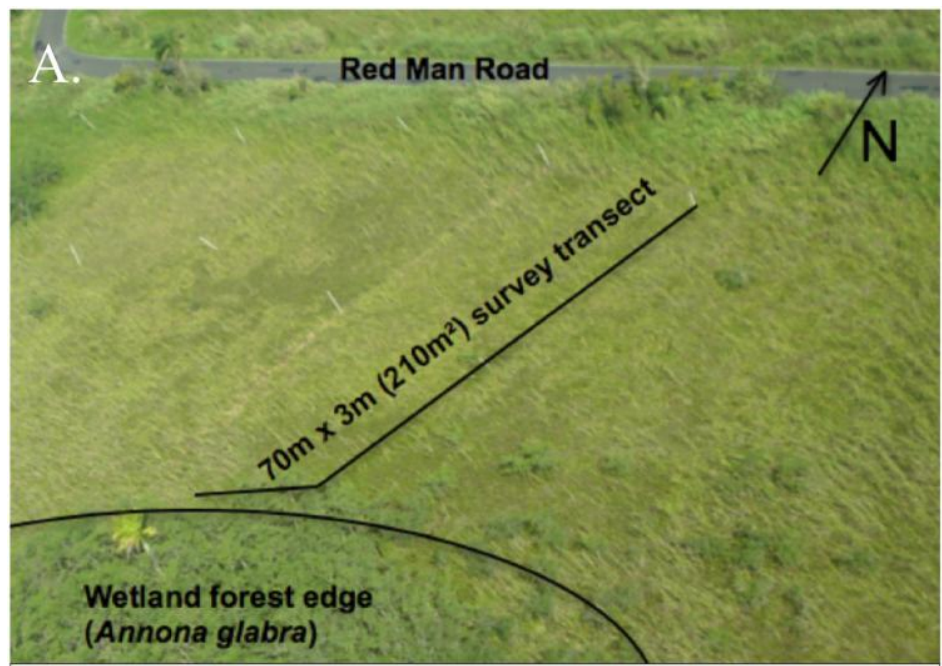

B.

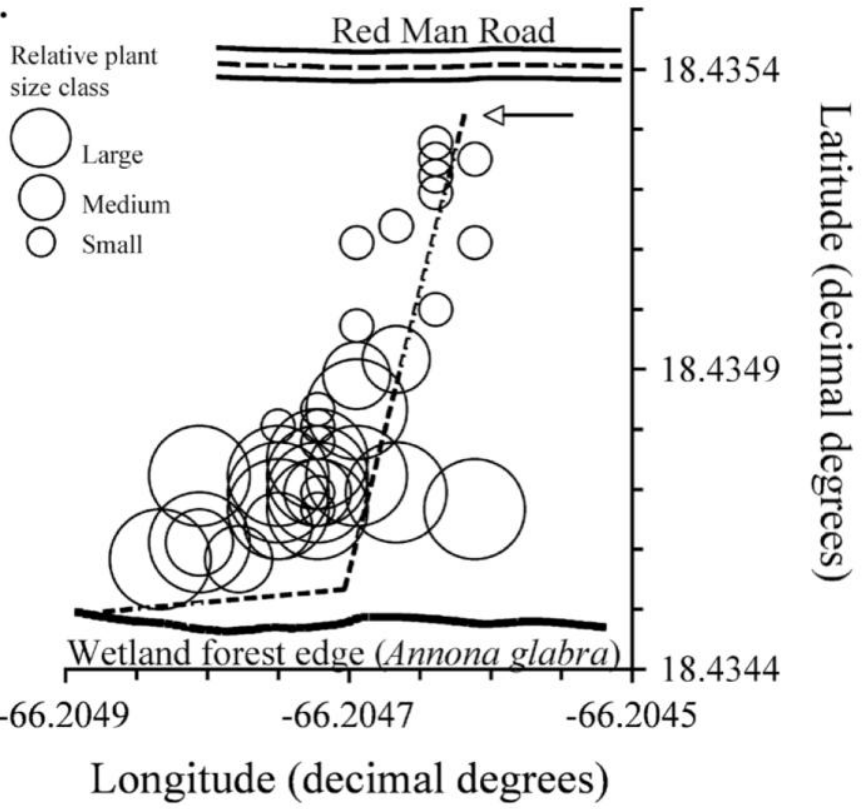

Figure 4. A. Aerial photograph of the $3 \times 70-\mathrm{m}$ census transect at Site 2 in the wetland. B. Approximate geographic location (latitude and longitude in decimal degrees) of Sagittaria lancifolia plants along this transect with circles representing the relative size of plants as described in the text. Arrow in B highlights location of the wetland margin in relation to the census transect. 
We found a skewed distribution of the frequency of leaf axils in each size class, and of the frequency of egg masses deposited among leaf axils of $S$. lancifolia (Figure 5). Of 74 leaf axils examined, we found 23 egg masses deposited in leaf axils with inner width in the size classes between 6-9 $\mathrm{mm}$ and 15-18 mm. The 9-12 mm size class of internal width of leaf axil, however, had more egg masses $(13$ or $56.5 \%)$ than expected $\left(G_{a d j, 5}=16.6, P<0.006\right)$ (Figure 5). Proportionally, more egg masses were deposited in leaf axils with smaller widths ( 6 clutches or $26.1 \%$ in $<9 \mathrm{~mm}$ ) than larger widths (4 clutches or $17.4 \%$ in $>12 \mathrm{~mm}$ ) (Figure 5).

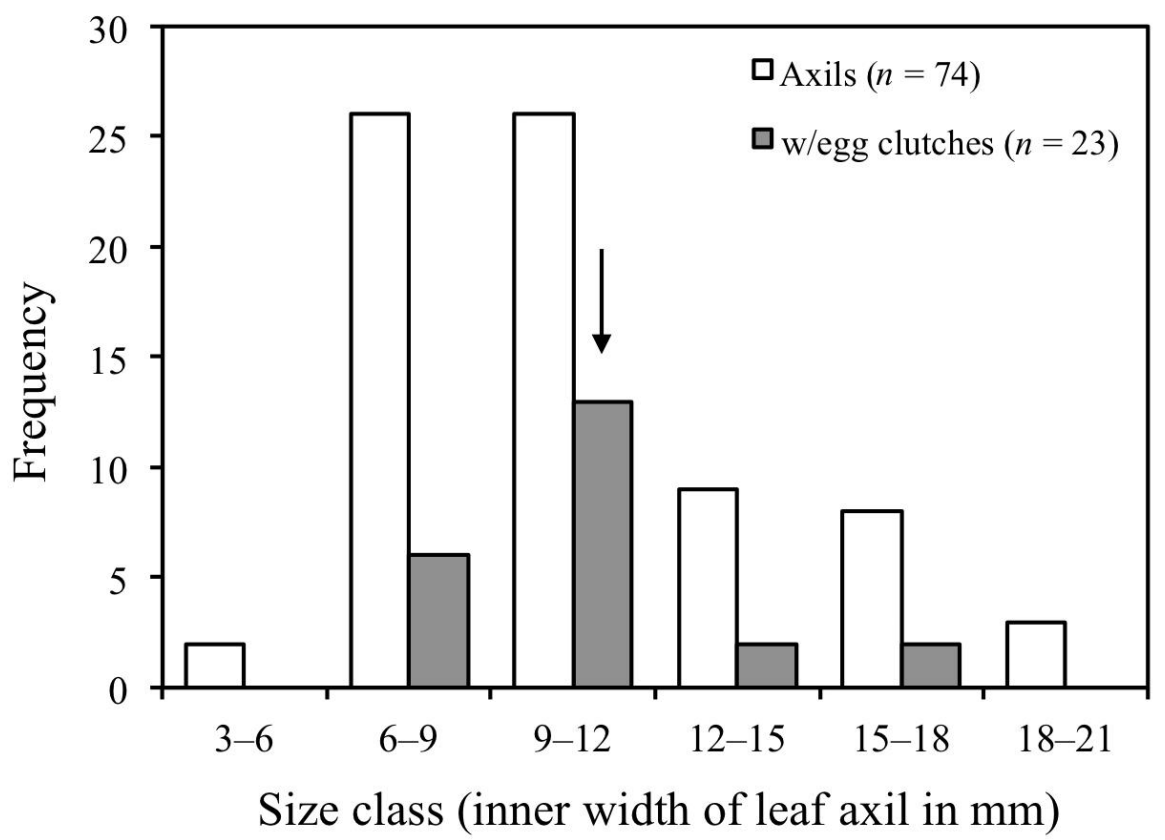

Figure 5. Available oviposition sites (leaf axils of Sagittaria lancifolia) categorized by size of inner width of axil (open columns) and frequency of egg clutches of $E$. juanariveroi found in axils of each size class (filled columns). The arrow highlights leaf axil size class with significant higher frequency of egg masses than expected.

Reproductive biology of E. juanariveroi. Production of egg clutches by $E$. juanariveroi included multiple egg masses in a single nest site, and different egg masses deposited next to one another frequently had embryos that looked similar (Figures 6A-C). Of 111 egg clutches in nests found by 24 March 2013 between sites 1-3, 91 clutches had a single egg mass (82.0\%), 16 clutches had two egg masses (14.4\%), and four clutches consisted of three egg masses (3.6\%) (Figure 6D). None of $97 \mathrm{egg}$ clutches (including single and multiple) of E. juanariveroi 

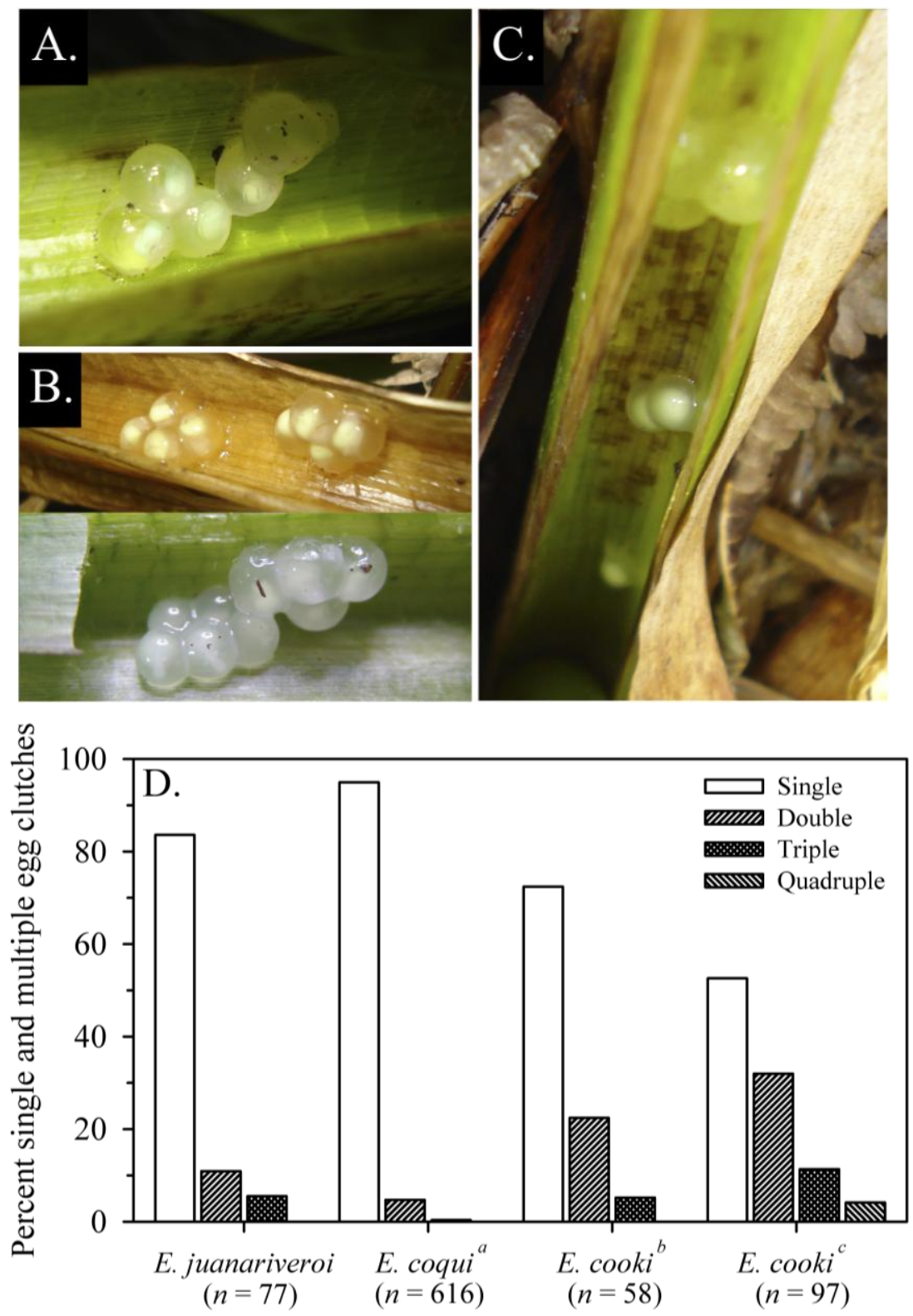

Figure 6. A-C. Single and multiple egg clutches of E. juanariveroi found in leaf axils of Sagittaria lancifolia. D. Frequency of single and multiple egg clutches in $E$. juanariveroi compared with E. coqui and E. cooki ( ${ }^{a}$ data of E. coqui from Townsend et al., 1984; b data of E. cooki from Joglar et al., 1996; ${ }^{\text {c }}$ data of E. cooki from Burrowes 2000). 

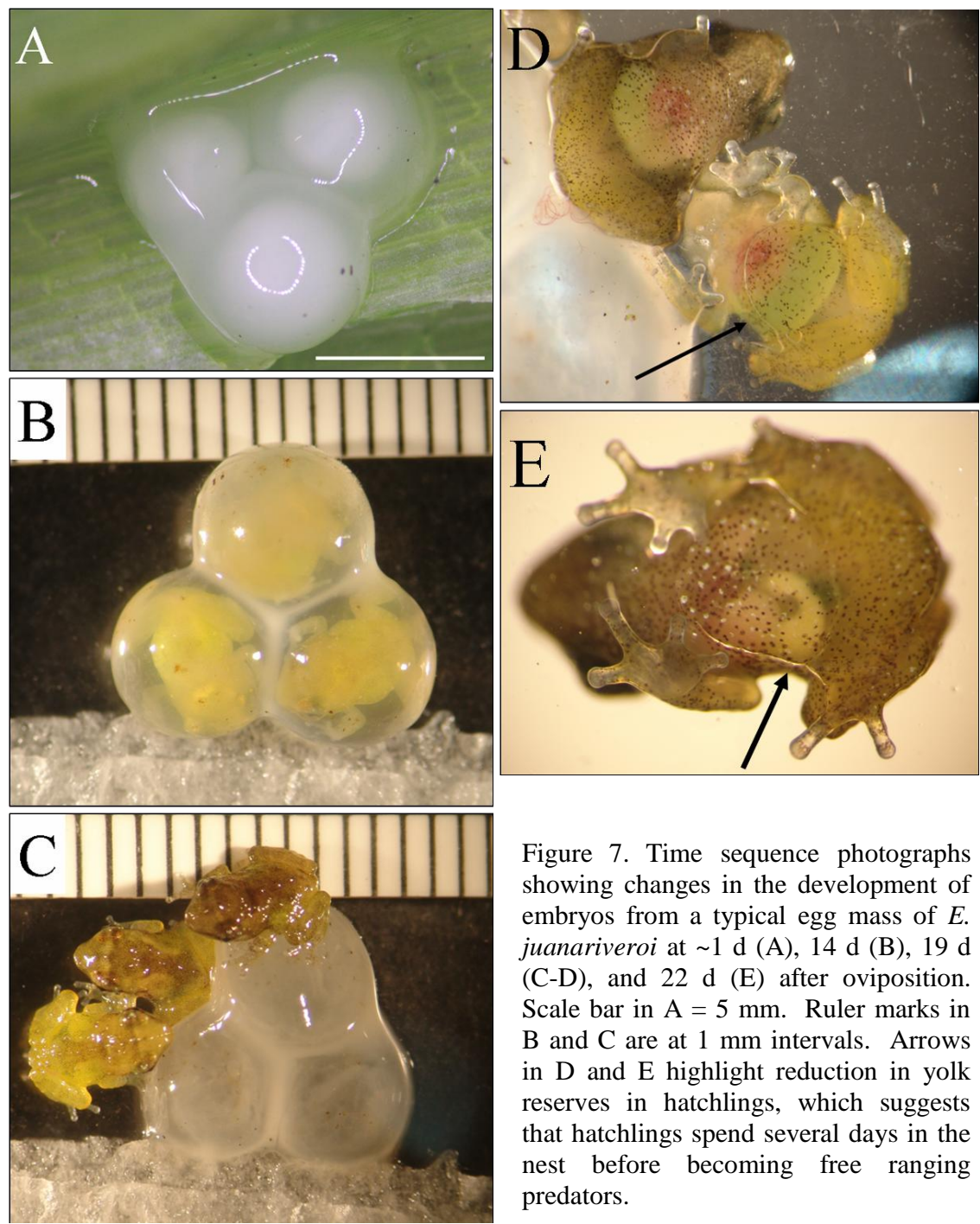

Figure 7. Time sequence photographs showing changes in the development of embryos from a typical egg mass of $E$. juanariveroi at $\sim 1 \mathrm{~d}(\mathrm{~A}), 14 \mathrm{~d}(\mathrm{~B}), 19 \mathrm{~d}$ (C-D), and $22 \mathrm{~d}(\mathrm{E})$ after oviposition. Scale bar in $A=5 \mathrm{~mm}$. Ruler marks in $\mathrm{B}$ and $\mathrm{C}$ are at $1 \mathrm{~mm}$ intervals. Arrows in $\mathrm{D}$ and $\mathrm{E}$ highlight reduction in yolk reserves in hatchlings, which suggests that hatchlings spend several days in the nest before becoming free ranging predators.

have been found with an adult brooding. An adult may be rarely found at the nonflooded base of a leaf axil near or in the leaf axil where an egg clutch is found (15 out of $97 \mathrm{egg}$ clutches with an adult near the leaf axil or $15.5 \%$ of observations), and it will submerge in water at the base of the leaf axil when disturbed by the observer. External visual inspection of gravid females revealed 
one to four eggs in their oviducts (mean $=2.9 \pm 0.9$ eggs, $n=14$ ), which suggests that females lay all eggs after mating.

In 2005, we collected a recently laid egg mass of three eggs from a leaf axil of S. lancifolia in the field (Figure 7A). We placed the egg mass on a dampened cheese cloth in a small petri dish for observation of egg survival and embryo development in the laboratory. The embryos developed normally (Figure 7B), we did not observe fungi/microbes growing on the outer surface of the egg jelly, and embryos hatched in $19 \mathrm{~d}$ at $22{ }^{\circ} \mathrm{C}$ (Figure 7C). The hatchlings remained closely grouped for three days while absorbing most of their yolk reserve and then dispersed in the petri dish (Figures 7D-E). In the field, we found a recently laid egg mass of five eggs on 16 October 2012 and hatching occurred by 4 November 2012 ( 19 d after deposition). One hatchling, however, was still found in the same leaf axil by 19 November 2012 ( 15 days after hatching).

In the field, nearly all eggs in a mass of E. juanariveroi are fertilized (we have found one unfertilized egg only among 131 egg masses examined), and all embryos either hatch or all eggs die, presumably because of predation (common) and dehydration (rare). Clutch survival outside the enclosures (natural setting) was $64.9 \%$ ( $n=37$ egg masses followed from being recently deposited to hatching or disappearing). Clutch survival in the field enclosure experiments was $62.0 \%$, which resulted in 13 egg masses that hatched without a guarding adult and eight egg masses that were predated $(n=6)$ and decomposed $(n=2)$ for unknown reasons (Figure 8). We found no significant difference in percent hatching success between enclosures and natural settings $(P=1$, Fisher's exact test).

Leaf axils of Sagittaria lancifolia frequently harbored adults E. cochranae (Whistling Coquí) and invertebrates like land mollusks, crickets, and several species of ants (Figure 9). On several occasions, we recorded evidence of egg clutch predation/destruction of E. juanariveroi because of: E. cochranae and crickets (Figure 9A); the complete disappearance of gelatinous mass and eggs, presumably by mollusks, at a previously marked nest site (Figure 9B-D); predation by ants (Figure 9E); and destruction of gelatinous mass and egg capsules by E. cochranae (Figure 9F-G). We have also found egg clutches of two Eleutherodactylus species (E. cochranae and E. coqui), and eggs from two species of lizards (the Grass Anole, Anolis pulchellus Duméril and Bibron, 1837, and the Eyespot Sphaero, Sphaerodactylus macrolepis Günther, 1859) in the leaf axils of this plant. 

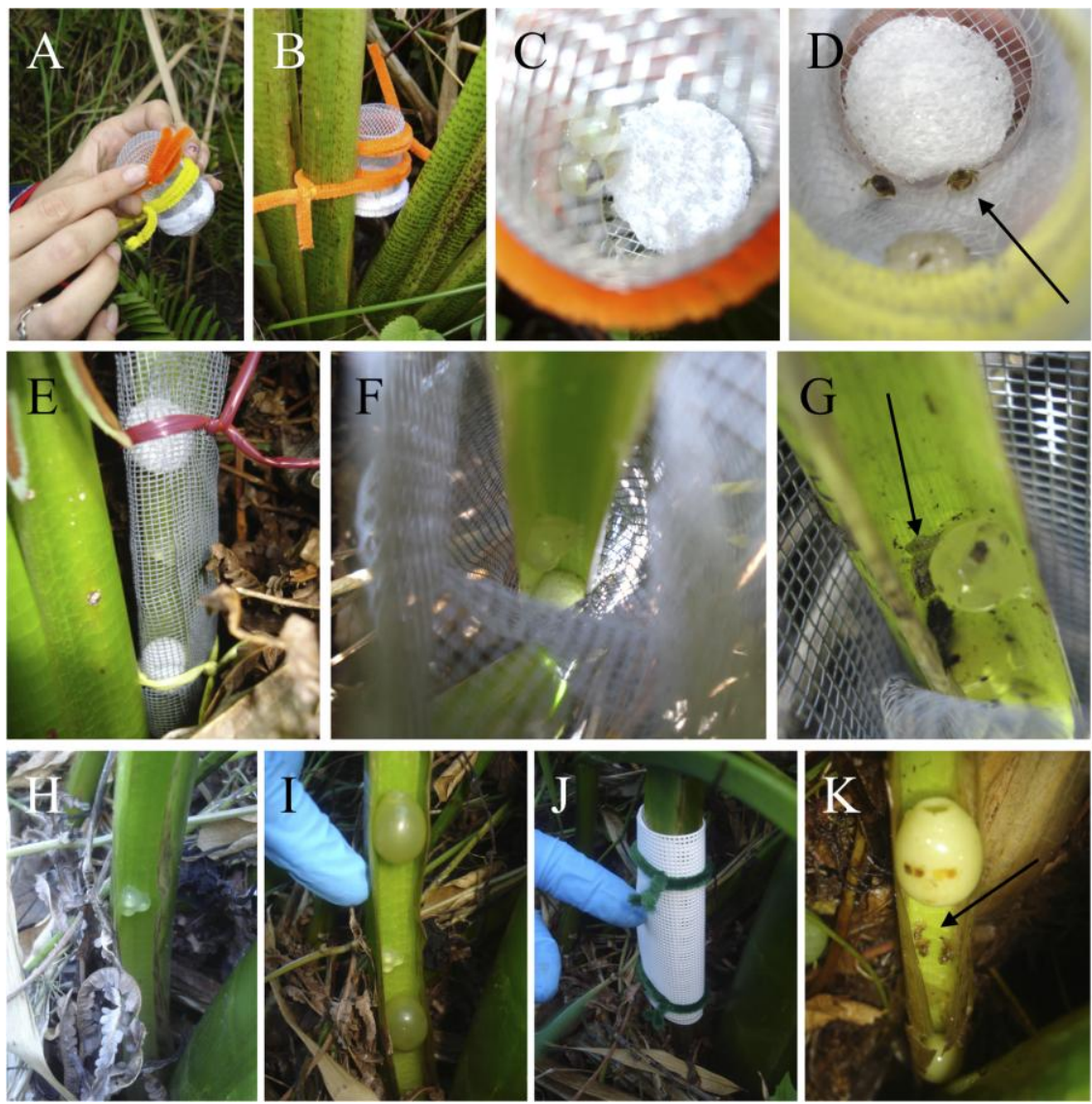

Figure 8. A - D. Three field enclosure devices to examine egg development and hatching without guarding/brooding adults of E. juanariveroi. An egg mass placed in a plastic tube covered by metal screen mesh at both open ends, and tied to the exact location of the egg mass in its leaf axil. E - G. An egg mass enclosed in its leaf axil by a nylon covered string screen mesh with both openings in the leaf axil sealed with foam balls. $\mathrm{H}-\mathrm{K}$. An egg mass enclosed in its leaf axil by a plastic screen mesh with both openings in the leaf axil sealed with artificial grape fruits made of rubber. Size mesh in $A-D$ and $E-G=1$ $\mathrm{mm}$. Size mesh in $\mathrm{H}-\mathrm{K}=0.5 \mathrm{~mm}$. Percent hatching success among enclosure designs was $53 \%$ (9/17) from designs $A-G$ with a $1 \mathrm{~mm}$ mesh size and $100 \%$ (4/4) from design $\mathrm{H}-\mathrm{K}$ with a $0.5 \mathrm{~mm}$ mesh size. Arrow in $\mathrm{D}, \mathrm{G}$, and $\mathrm{K}$ highlights hatchlings from each design. 

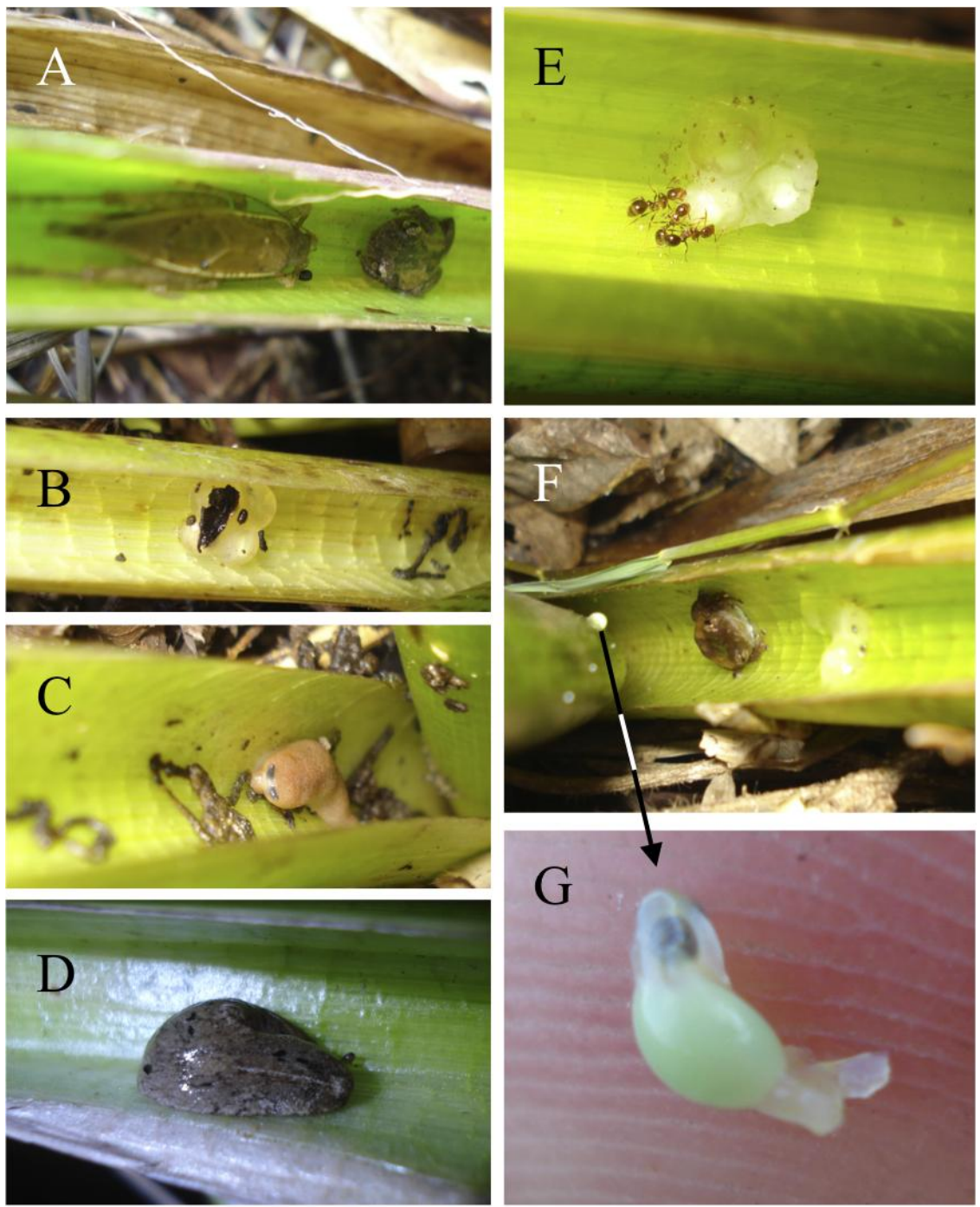

Figure 9. Egg clutch predation/destruction and several predators of eggs of $E$. juanariveroi documented from the leaf axils of Sagittaria lancifolia: A. Eleutherodactylus cochranae and an unidentified cricket (Gryllidae). B. Egg clutch of E. juanariveroi and feces from a potential predator Veronicella sp. (native land slug). C. The introduced slug, Deroceras laeve (O. F. Müller, 1774), found in a previous location of a recently deposited egg clutch. D. Detail of Veronicella sp. E. Solenopsis sp. ants. F. Egg disruption by E. cochranae. G. Close up of E. juanariveroi embryo from (F) out of the egg. 


\section{Discussion}

The pattern of monthly variation in population density of $E$. juanariveroi was consistent with patterns documented for other Puerto Rican Eleutherodactylus (except for E. unicolor; Joglar, 1998): density decreases during months with lower temperature and less rainfall (i.e. between January and April) and increases during months with higher temperature and greater rainfall (i.e. between May and December) (e.g. E. cooki [Joglar et al., 1996]; E. coqui, E. gryllus, and E. portoricensis [Joglar, 1998]). Similar to all Puerto Rican Eleutherodactylus, E. juanariveroi is active year round, but its population phenology was explained by rainfall only, which contrast with the relationship between climate variables and population phenology of all Eleutherodactylus in this wetland (Appendix 2). This relationship was unexpected because waterrelated variables are unlimited resources in the wetland and because the species' reproductive mode (i.e. direct development of terrestrial eggs) was expected to be less dependent on rainfall for hatching success (e.g. compared with temperature-related variables). The generality of the relationship between population phenology and rainfall in wetland Eleutherodactylus needs further study, particularly when two Eleutherodactylus species are described exclusively from wetland situations so far (e.g. Hedges and Thomas, 1992; RíosLópez and Thomas, 2007; Hedges et al., 2008).

In Puerto Rico, comparable data exist on the relative contribution of climate variables and population phenology for two of the most studied Eleutherodactylus, E. cooki and E. coqui (Henderson and Powell, 2009), but interpretation of results varies and has profound implications for conservation purposes. In E. cooki, for example, Joglar et al. (1996) reported that production of egg clutches corelated significantly with total monthly precipitation and mean air temperature in caves. In the same cave habitat, Rogowitz et al. (2001), however, documented that most of the variation in egg clutch production of $E$. cooki was explained only by small variations in the thermal environment in caves, in which production of egg clutches increases when surface temperature of rocks increases. In E. coqui from El Yunque National Forest in the Luquillo mountains, Stewart (1995) documented that the daily distribution of rain at midelevation areas ( $350 \mathrm{~m}$ asl), rather than total rainfall (monthly or annual), is the main driver of population density of E. coqui. In the same mountain range, but at a higher elevation area (661 m asl), Joglar (1998) documented that monthly mean air temperature is the main driver of the variation in population density of $E$. coqui. These two scenarios on the population dynamics of $E$. coqui originated from locations that differ by $2^{\circ} \mathrm{C}$ in mean annual temperature and by $636 \mathrm{~mm}$ in total annual rainfall only (see García-Martinó et al., 1996). In Sabana Seca, the population phenology of E. juanariveroi was placed in the context of other sympatric Eleutherodactylus, but the same climate variables explained their population phenologies differently (Figure 2D and Appendix 2). Consequently, projected climate change poses challenges to conservation measures for 
Eleutherodactylus in general, and for those deemed threatened (E. cooki) and endangered (E. juanariveroi) in particular, because prediction of population dynamics relies on a better understanding of the mechanisms generating the phenomenom of interest, and the type of climate data being collected may result in different interpretations of the same population pattern (see Levin, 1992).

All Puerto Rican Eleutherodactylus exhibit parental care and brood their eggs in clutches (in species for which reproductive data exists and except for the ovoviviparous E. jasperi). These are reproductive strategies to reduce water loss, egg desiccation, and predation, and increase hatching success (see Taigen et al., 1984; reviewed in Joglar, 1998; Burrowes, 2000). Along with direct development, these strategies may also allow Eleutherodactylus species to become less dependent on rainfall for breeding compared with ambient air temperature. However, we have not observed parental care in E. juanariveroi (see next) nor parents rehydrating eggs in masses (e.g. immersion in water and rehydrating eggs nor engaged in brooding behaviors). The eggs in masses of this species are enclosed in a thick jelly coat, which is unique among Puerto Rican Eleutherodactylus (Figures 6A-C and 7A), and this jelly coat may protect the eggs from dehydration if air humidity levels are very high (as it is in Sabana Seca). Previous studies have shown that egg jelly coat may protect eggs from predation and from microbial/fungi overgrow (e.g. Altig and McDiarmid, 2007; Touchon, 2012), which can be particularly important in the absence of parental attendance in E. juanariveroi (N. Ríos-López, unpublished data). Consequently, egg morphology could play a significant role for the maintenance of egg's internal osmotic condition and protection from external variables (e.g. Beuchat et al., 1984; Altig and McDiarmid, 2007) leading to high levels of hatching success, particularly in the absence of parental care.

Lack of parental care in E. juanariveroi was unexpected: we have found none of the 131 egg masses with a brooding adult, and we have not observed egg defense when an adult is found near an egg clutch at the base of the leaf axil (e.g. compared with aggresive behavior documented by Townsend et al. [1984] in E. coqui). According to Townsend's (1996) criteria for documenting lack of parental care in Eleutherodactylus, two to three published and unpublished observations of eggs without an attendant are indicative of a species that lacks parental care. In these criteria, Eleutherodactylus species without parental attendance only include E. planirostris (Cope, 1862) from Cuba and E. gossei Dunn, 1926 from Jamaica (Townsend, 1996; Hedges et al., 2008). On the other hand, Townsend and Stewart (1994), and Burrowes (2000), suggest that high levels of hatching success in E. coqui $(60 \%)$ and E. cooki $(85 \%)$ result directly from activities of parental care, which include egg attendance, egg brooding, and guarding with aggressive behaviors. Fitness cost of lack of parental care in these species is considerable: when adults were experimentally removed from egg clutches, hatching success in E. coqui $(23.1 \%)$ and in E. cooki $(0 \%)$ were dramatically low, with most egg clutches being lost to egg predation, 
dehydration, and microbial infections (Townsend et al., 1984; Burrowes, 2000). In E. juanariveroi, the fact that hatching success in field enclosure experiments $(62.0 \%)$ reached levels similar to hatching success observed from the field $(64.9 \%)$, and given the large proportion of egg clutches found without a nearby adult $(84.5 \%)$, provide evidence highly suggestive of a species that lacks parental attendance of eggs. Consequently, E. juanariveroi represents the third species in the genus without parental care sensu Townsend (1996).

Microhabitat conditions seemed vital also for the maintenance of $E$. juanariveroi's population dynamics. The species utilizes ferns, mostly as perching and calling sites (Figure 3), while utilizing leaf axils of S. lancifolia for egg laying and retreat (Figures 4 and 5). In fact, egg clutches of E. juanariveroi have been found exclusively on leaf axils of $S$. lancifolia, but this plant represents a limited resource (7.4\% vegetation cover in the wetland) in high demand by a wide range of organisms for breeding, retreat, and forage (Figure 9). In addition, a small difference in water depth and size of S. lancifolia translates into a large difference in egg clutch deposition (Figures 4 and 5) suggesting this plant as an important retreat and breeding site under the influence of hydrological conditions.

We believe that the species' population dynamics are regulated by the synergism between availability of suitable $S$. lancifolia for reproduction and seasonality in rainfall. Egg production in E. juanariveroi, however, decreases during the dry season (between January and April; Appendix 3) when dry area for terrestrial predators like ants (and presumably of other invertebrates) increases. Consequently, future studies may examine the influence of seasonality (e.g. hydroperiodicity) on prey abundance (as a surrogate for carbon, nutrients, and energy available for egg production) and on predator abundance (as a surrogate for predation pressure) to determine the relative contribution of each factor (prey and predator abundance) to the species' seasonality in egg production.

Production of multiple egg clutches has been documented only from Eleutherodactylus species that show male parental attendance of eggs (Townsend, 1996). Production of multiple clutches has direct consequences for population size, but has also been interpreted as a reproductive strategy that provides a significant fitness value to guarding males with no costs of energy expenditure or loss of mating opportunities (e.g. as documented in E. cooki by Burrowes, 2000). Eleutherodactylus juanariveroi has the second highest frequency of multiple clutches produced among Puerto Rican Eleutherodactylus (E. cooki being the first), and the species shows strong site dependency for egg deposition with no parental care. A single plant rarely harbors more than one egg clutch of $E$. juanariveroi in different leaf axils and the fact that the vast majority of embryos in multiple clutches deposited in the same leaf axil are similar in appearance suggests that multiple clutches are from the same male and different females. Finally, evidence presented herein suggests that egg 
attendance by adults is not required for hatching success and we have noted that egg morphology in E. juanariveroi seems unique among Puerto Rican Eleutherodactylus. We believe that some attributes of egg morphology in $E$. juanariveroi may facilitate production of multuple clutches by reducing related costs of energy expenditure in parental care acivities like brooding and rehydration. Nonetheless, future studies may examine the importance of egg morphology (or other egg-related variable) to increased fitness in the absence of parental care in an anuran genus characterized by direct development of terrestrial eggs.

Conservation Implications. Eleutherodactylus juanariveroi is listed endangered and the wetland area inhabited by the species faces a myriad of threats from human activities and climate change (USFWS, 2012). This study puts the ecology of the species in the context of habitat characteristics, climate variables, sympatric Eleutherodactylus, and other biotic elements that influence the population dynamics of E. juanariveroi. Given that conservation measures may include captive breeding programs for introduction of the species in suitable and protected wetland areas inland, information provided herein could be valuable for the development and implementation of effective species recovery plans, protection of suitable wetlands for the establishment of managed populations, and should help minimize the consequences of delayed conservation actions in a rapidly changing environment.

\section{Acknowledgments}

We are indebted to J. González from the Caribbean Primate Research Center for logistical support in Sabana Seca; J.D. Daza for preparing the map in Figure 1; F. Axelrod for surveying and plant identification; the Puerto Rico Commonwealth Department of Natural and Environmental Resources for issuing collection permits 01-IC-068 and 05-IC-068 to NRL; E. Agosto-Torres, J. M. Álvarez-Del Valle, E. M. Díaz-Negrón, Y. M. Flores-Rodríguez, I. N. Irizarry-Pérez, E. L. LozadaDelgado, R. Maldonado-Maldonado, N. V. Martínez-González, D. Reyes-De Jesús, W. RuízVázquez, J. Soto-Burgos, and C. Vicéns-López for their assistance in data collection; and three anonymous reviewers that greatly improved this manuscript.

\section{Literature Cited}

Altig, R., and R. McDiarmid. 2007. Morphology diversity and evolution of eggs and clutch structure in amphibians. Herpetological Monographs 21:1-32. http://dx.doi.org/10.1655/06-005.1

Beuchat, C. A., F. H. Pough, and M. M. Stewart. 1984. Response to simultaneous dehydration and thermal stress in three species of Puerto Rican frogs. Journal of Comparative Physiology B 154:579-585. http://dx.doi.org/10.1007/BF00684411

Blaustein, A. R., B. A. Han, R. A. Relyea, P. T. J. Johnson, J. C. Buck, S. S. Gervasi, and L. B. Kats. 2011. The complexity of amphibian population declines: understanding the role of cofactors in driving amphibian losses. Annals of the New York Academy of Sciences 1223:108-119. http://dx.doi.org/10.1111/j.1749-6632.2010.05909.x

Brodman, R., M. Parrish, H. Kraus, and S. Cortwright. 2006. Amphibian biodiversity recovery in a large-scale ecosystem restoration. Herpetological Conservation Biology 1:101-108.

Burrowes, P. A. 2000. Parental care and sexual selection in the Puerto Rican Cave-Dwelling frog, Eleutherodactylus cooki. Herpetologica 56:375-386.

Burrowes, P. A., R. L. Joglar, and D. E. Green. 2004. Potential causes for amphibian declines in Puerto Rico. Herpetologica 60:141-154. http://dx.doi.org/10.1655/03-50 
Crump, M. L. and N. J. Scott. 1994. Visual encounter surveys. pp. 84-92. In, W. R. Heyer, M. A. Donnelly, R. W. McDiarmid, L. C. Hayek, and M. S. Foster (Editors). Measuring and Monitoring Biological Diversity: Standard Methods for Amphibians. Smithsonian Institution Press. Washington, District of Columbia, USA. 364 pp.

Eusse, A. M. and T. M. Aide. 1999. Patterns of litter production across a salinity gradient in a Pterocarpus officinalis tropical wetland. Plant Ecology 145:307-315. http://dx.doi.org/10.1023/A:1009832627166

Ewel, J. J. and J. L. Whitmore. 1973. The Ecological Life Zones of Puerto Rico and the U. S. Virgin Islands. Forest Service. U.S. Department of Agriculture. Institute of Tropical Forestry, US Forest Service Research Paper ITF-18. Río Piedras, Puerto Rico. 72 pp.

Fong , G., A., J.-M Hero, R. Vina, and I. Bignotte-Giro. 2010. Population ecology of the riparian frog Eleutherodactylus cuneatus in Cuba. Biotropica 42:348-354. http://dx.doi.org/10.1111/i.1744-7429.2009.00592.x

García-Martinó, A. R., G. S. Warner, F. N. Scatena, and D. L. Civco. 1996. Rainfall, runoff and elevation relationships in the Luquillo mountains of Puerto Rico. Caribbean Journal of Science 32:413-424.

Gibbons, J. W., D. E. Scott, T. J. Ryan, K. A. Buhlmann, T. D. Tuberville, B. S. Metts, J. L. Greene, T. Mills, Y. Leiden, S. Poppy, and C. T. Winne. 2000. The global decline of reptiles, déjà vu amphibians. BioScience 50:653-666. $\quad$ http://dx.doi.org/10.1641/00063568(2000)050[0653:TGDORD]2.0.CO;2

Hedges, S. B. and R. Thomas. 1992. A new marsh-dwelling species of Eleutherodactylus from Haiti (Anura: Leptodactylidae). Journal of Herpetology 26:191-195. http://dx.doi.org/10.2307/1564861

Hedges, S. B., W. E. Duellman, and M. P. Heinicke. 2008. New World direct-developing frogs (Anura: Terrarana): Molecular phylogeny, classification, biogeography, and conservation. Zootaxa 1737:1-182.

Henderson, R. W. and R. Powell. 2009. Natural History of West Indian Reptiles and Amphibians. University Press of Florida. Gainesville, Florida, USA. 528 pp.

IUCN (International Union for Conservation of Nature). 2012. The IUCN Red List of Threatened Species, Version 2012.2. http://www.iucnredlist.org. Downloaded on 6 December 2012.

Joglar, R. L. 1998. Los Coquíes de Puerto Rico: Su Historia Natural y Conservación. Editorial de la Universidad de Puerto Rico, USA. 232 pp.

Joglar, R. L., P. A. Burrowes, and N. Ríos. 1996. Biology of the Puerto Rican cave-dwelling frog, Eleutherodactylus cooki, and some recommendations for its conservation. pp. 251-258. In, R. Powell and R.W. Henderson (Editors). Contributions to West Indian Herpetology: a Tribute to Albert Schwartz. SSAR Contributions to Herpetology (St. Louis, Missouri, USA) 12, 457 pp.

Levin, S. A. 1992. The problem of pattern and scale in ecology: the Robert H. MacArthur Award Lecture. Ecology 73:1943-1967. http://dx.doi.org/10.2307/1941447

Mitsch, W. J. and J. G. Gosselink. 2007. Wetlands. $4^{\text {th }}$ Edition. John Wiley and Sons, Inc. Hoboken, New Jersey, USA. 600 pp.

Ríos-López, N. and R. Thomas. 2007. A new species of palustrine Eleutherodactylus (Anura: Leptodactylidae) from Puerto Rico. Zootaxa 1512:51-64.

Rogowitz, G. L., C. L. Candelaria, L. E. Denizard, and L. J. Meléndez. 2001. Seasonal reproduction of a Neotropical frog, the cave coquí (Eleutherodactylus cooki). Copeia 2001:542-547. http://dx.doi.org/10.1643/0045-8511(2001)001[0542:SROANF]2.0.CO;2

Semlitsch, R. D. and J. R. Bodie. 1998. Are small, isolated wetlands expendable? Conservation Biology 12:1129-1133. http://dx.doi.org/10.1046/j.1523-1739.1998.98166.x

Sokal, R. R. and F. J. Rohlf. 1995. Biometry: The Principles and Practice of Statistics in Biological Research. Fourth Edition. W.H. Freeman and Company. New York, New York, USA. 937 pp.

Stewart, M. M. 1995. Climate driven population fluctuations in rain forest frogs. Journal of Herpetology 29:437-446. http://dx.doi.org/10.2307/1564995

Taigen, T. L., F. H. Pough, and M. M. Stewart. 1984. Water balance of terrestrial anuran (Eleutherodactylus coqui) eggs: importance of parental care. Ecology 65:248-255. http://dx.doi.org/10.2307/1939477 
Touchon, J. C. 2012. A treefrog with reproductive mode plasticity reveals a changing balance of selection for nonaquatic egg laying. The American Naturalist 180:733-743. http://dx.doi.org/10.1086/668079

Townsend, D. S. 1996. Patterns of parental care in frogs of the genus Eleutherodactylus. pp. 229239. In, Powell, R. and R.W. Henderson (Editors). Contributions to West Indian Herpetology: a Tribute to Albert Schwartz. SSAR Contributions to Herpetology (St. Louis, Missouri, USA) $12,457 \mathrm{pp}$.

Townsend, D. S. and M. M. Stewart. 1994. Reproductive ecology of the Puerto Rican frog Eleutherodactylus coqui. Journal of Herpetology 28:34-40. http://dx.doi.org/10.2307/1564677

Townsend, D. S., M. M. Stewart, and F. H. Pough. 1984. Male parental care and its adaptive significance in a Neotropical frog. Animal Behaviour 32:421-431. http://dx.doi.org/10.1016/S0003-3472(84)80278-X

USFWS (United States Fish and Wildlife Service). 2012. Endangered and threatened wildlife and plants; determination of endangered species status for Coquí Llanero throughout its range and designation of critical habitat, final rule. Federal Register 77:60778-60802.

Young, B. E., K. R. Lips, J. K. Reaser, R. Ibáñez, A. W. Salas, J. R. Cedeño, L. A. Coloma, S. Ron, E. La Marca, J. R. Meyer, A. Muñoz, F. Bolaños, G. Chaves, and D. Romo. 2001. Population declines and priorities for amphibian conservation in Latin America. Conservation Biology 15:1213-1223. http://dx.doi.org/10.1046/j.1523-1739.2001.00218.x

Zimmerman, B. L. 1994. Audio strip transects. pp. 92-97. In, W. R. Heyer, M. A. Donnelly, R. W. McDiarmid, L. C. Hayek, and M. S. Foster (Editors). Measuring and Monitoring Biological Diversity: Standard Methods for Amphibians. Smithsonian Institution Press. Washington, District of Columbia, USA. 364 pp. 
Appendix 1. List of plant species found in the palustrine herbaceous wetland from Sabana Seca, Toa Baja, Puerto Rico and deposited at the University of Puerto Rico-Río Piedras Campus Herbarium (voucher number shown).

\begin{tabular}{|c|c|c|}
\hline Family & Species & $\begin{array}{c}\text { Herbarium } \\
\text { Number- } \\
\text { UPRRP }\end{array}$ \\
\hline Alismataceae & Sagittaria lancifolia $\mathrm{L}$. & 13271 \\
\hline Blechnaceae & Blechnum serrulatum Rich. & 13282 \\
\hline \multirow[t]{3}{*}{ Bromeliaceae } & Tillandsia fasciculata $\mathrm{Sw}$. & 13301 \\
\hline & Tillandsia polystachia (L.) L. & 13300 \\
\hline & Tillandsia recurvata (L.) L. & 13299 \\
\hline Compositae & Mikania micrantha Kunth & 13294 \\
\hline \multirow[t]{2}{*}{ Convolvulaceae } & Ipomoea setifera Poir. & 13284 \\
\hline & Ipomoea tiliacea (Willd.) Choisy & 13287 \\
\hline \multirow[t]{8}{*}{ Cyperaceae } & Cyperus haspan $\mathrm{L}$. & 13279 \\
\hline & $\begin{array}{l}\text { Eleocharis interstincta (Vahl) Roem. and } \\
\text { Schult }\end{array}$ & 13274 \\
\hline & Fuirena umbellata Rottb. & 13278 \\
\hline & Leersia hexandra Sw. & 13276 \\
\hline & $\begin{array}{l}\text { Oxycaryum cubense (Poeppig and Kunth) } \\
\text { Lye }\end{array}$ & 13273 \\
\hline & Rhynchospora corymbosa (L.) Britton & 13275 \\
\hline & $\begin{array}{l}\text { Scleria melaleuca Rchb. ex Schltdl. and } \\
\text { Cham. }\end{array}$ & $13303 \mathrm{~A}$ \\
\hline & Scleria microcarpa Nees ex Kunth & 13288 \\
\hline Gramineae & Panicum parvifolium Lam. & 13286 \\
\hline Lauraceae & Cassytha filiformis $\mathrm{L}$. & 13280 \\
\hline \multirow{5}{*}{$\begin{array}{l}\text { Leguminosae- } \\
\text { Papilionoideae }\end{array}$} & Centrosema pubescens Benth. & 13290 \\
\hline & Clitoria falcata Lam. & 13277 \\
\hline & Desmodium incanum DC. & 13272 \\
\hline & Vigna adenantha (G. Mey.) Maréchal et al. & 13293 \\
\hline & Vigna luteola (Jacq.) Benth. & 13283 \\
\hline Lemnaceae & Spirodela punctata (G. Mey) C. H. Thomps. & 13302 \\
\hline \multirow[t]{2}{*}{ Melastomataceae } & Miconia racemosa (Aubl.) DC. & 13295 \\
\hline & Nepsera aquatica (Aubl.) Naudin & 13291 \\
\hline Onagraceae & Ludwigia leptocarpa $\mathrm{H}$. Hara & 13292 \\
\hline Orchideaceae & Dendrobium crumenatum Sw. & 13166 \\
\hline Polygonaceae & Persicaria acuminata (Kunth) M. Gómez & 13304 \\
\hline \multirow[t]{2}{*}{ Rubiaceae } & Oldenlandia lancifolia (Schmach.) DC. & 13289 \\
\hline & Palicourea crosea (Sw.) Schult. & 13296 \\
\hline
\end{tabular}


Appendix 2. Variation in mean population density of sympatric Eleutherodactylus in E. juanariveroi's wetland habitat. Density of E. brittoni was significantly related with annual rainfall $\left(r_{s}=0.6768, P<0.04, n=10\right)$ and nocturnal relative humidity $\left(r_{s}=0.6403, P<0.05, n=10\right)$. Density of $E$. cochranae was associated, although not statistically significant, with diurnal ambient air temperature $\left(r_{s}=0.6121, P=0.0599, n=10\right)$. In contrast, density of E. coqui was significantly related with nocturnal ambient air temperature $\left(r_{s}=\right.$ $0.7134, P<0.03, n=10)$.

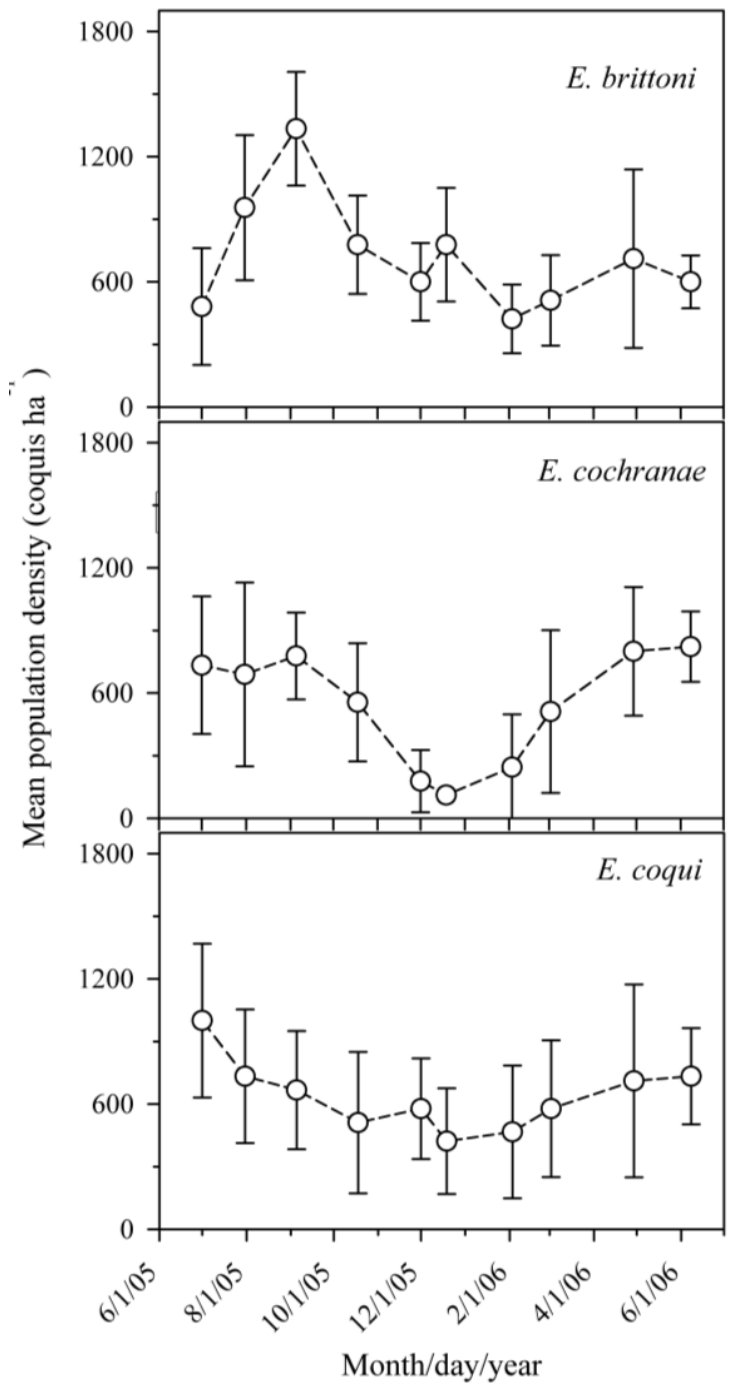


Appendix 3. Percent eggclutch production during the wet and dry season in 2009 (wet season, and the wet season in 2012 and dry season during 2013 at Site 2 (northern wetland) and Site 3 (southern wetland), respectively. Percent eggclutch production was calculated by the fraction of mean eggclutches found per person per weekly visit per season for each year period. In 2009, mean eggclutches found per person per weekly visit was $0.78( \pm 0.54 \mathrm{SD})$ during the dry season compared to 3.19 ( $\pm 3.76 \mathrm{SD}$ ) found during the wet season. In 2012 2013 , mean eggclutches found per person per weekly visit was 1.80 ( \pm 1.33 SD) during the dry season (2013) compared to 2.54 ( \pm 2.67 SD) found during the wet season (2012). More eggclutches per effort/time are frequently found during months of more rainfall (October-November) than during months of less rainfall (February-March), independent of year and site in the wetland.

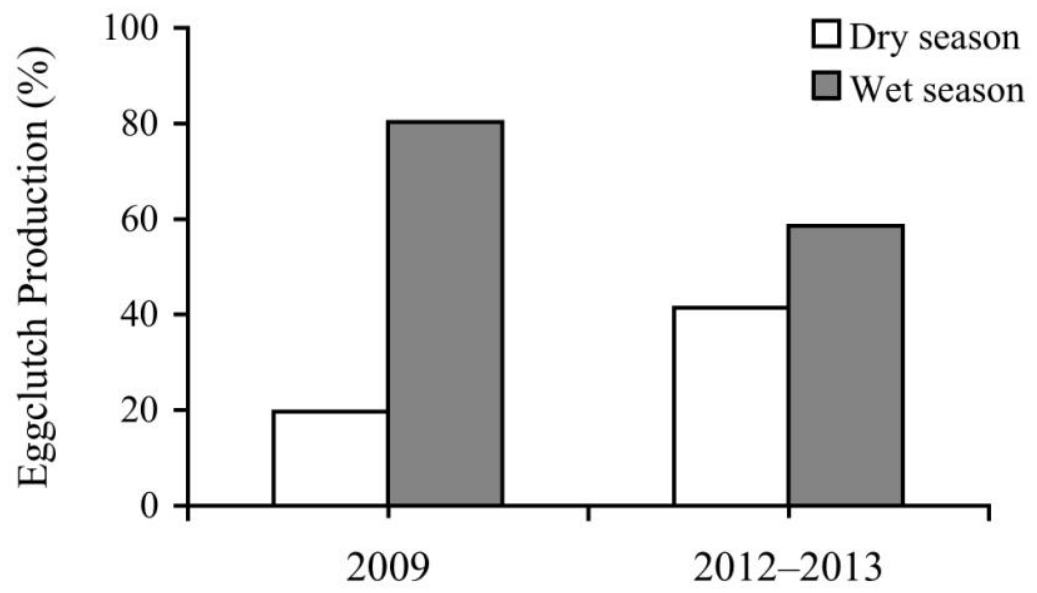

